\title{
SLE のサプレッサー機能
}

I. SLE のサプレッサー機能とB 細胞の異常

中村善一・浅野太郎・矢野啓介・大藤畺

\section{Suppressor function of patients with systemic lupus erythematosus : \\ I. Suppressor cells are generated normally in SLE by preculturing with or without Concanavalin A}

Zenichi Nakamura, Taro Asano, Keisuke Yano and Tadashi Ofuji.

3 rd Department of Internal Medicine, Okayama University, Medical School.

\section{【Summary]}

Peripheral mononuclear cells from patients with systemic Iupus erythematosus (SLE), when incubated for $48 \mathrm{hr}$ with or without concanavalin A (ConA), were found to be capable of inhibiting the pokeweed mitogen ( $P W M$ ) -induced polyclonal immunoglobulin (Ig) secretion by cells from normal individuals. Furthermore, these suppressor cells did not significantly affect on the Ig secretion by autologous B cells from patients with SLE. These results suggest that defective suppressive activity in patients with SLE is not at the $\mathrm{T}$ cell level, but, most likely, due to the defect of $\mathrm{B}$ cells in recognizing process of the suppressive information from suppressor $\mathrm{T}$ cells, caused by in vivo polyclonal $\mathrm{B}$ cell activation.

key words : Systemic lupus erythematosus ConA-induced suppressor cell Preculture-induced suppressor cell PWM-induced polyclonal Ig secretion Preactivation of $\mathrm{B}$ cell

\section{【概 要】}

SLE の未梢単核球を concanavalin A (Con A) 添加あるいは非添加で 48 時閒培養することにより, 正常同種単核 球による pokeweed mitogen (PWM) 刺激免疫グロブリン (Ig) 産生を抑制するところの, Con A-induced suppressor 細胞および preculture-induced suppressor 細胞を正常ヒトと同様に誘導することができた. しかし, SLEにおいて 誘導されたこの両 suppressor 細胞は, 正常ヒトのB細胞機能を抑制したが, 自己のB細胞に対しては十分に抑制効 果を示さないことが判明した.すなわち, SLEの suppressor 活性の異常は, むしろその情報を受けるB細胞の側に 欠宿があることが示唆された。 


\section{I. 緒 言}

polyclonal B cell activator のひとつである pokeweed mitogen (PWM) により, ヒトB細胞は抗体産 生細胞に分化し細胞質内に免疫グロブリン（Ig）を保有 するようになり，最終的には上清中に $\mathrm{Ig}$ を分泌するよ うになる ${ }^{1,2)}$ 。この反応には T 細胞が必要であり, suppressor $\mathrm{T}$ 細胞と helper $\mathrm{T}$ 細胞のバランスにより培養 上清中の Ig 量が左右される゙).

代表的な自己免疫疾患のひとつである全身性ループス エリテマトーデス（SLE）では多彩な自己抗体の産生と 多クローン性高ガンマグロブリン血症を伴い，抗体産生 系の機能六進が認められる.この免疫異常は in vitro でも認められ，著者らも報告してきたように, SLEの単 核球は培養液中に多量の Ig を無刺激にて分泌し4,5), PWM に対する反応性はかえって失われている4,6).

同様の B 細胞の機能方進は，ヒト SLE の疾患モデル である $\mathrm{NZB} / \mathrm{W}, \mathrm{BXSB}$ および MRL/l 系マウスでも生 後早期から認められている7). BXSB および MRL $/ l$ 系 マウスでは一般に suppressor活性は正常")だが, NZB/W $\mathrm{F}_{1}$ マウスでは加㱓とともに suppressor $\mathrm{T}$ 細胞の機能 異常が出現するという報告8)もあり， T細胞系の異常を 自己免疫の原因として重視する作業仮説 ${ }^{9}$ もあるが，こ れに反䮎しB細胞自体の異常，すなわち in vivoでの polyclonal activation を指摘する報告も最近では多い7, 10,11). Primi ら ${ }^{12)}$ は，B細胞が suppressor 情報を正常 に受けることができないことが原因であると報告してい る.

これまで，SLEの Con A-induced suppressor 細胞 は，リンパ球混合培養 (MLC) で観察される同種抗原に よるT細胞の幼若化反応 ${ }^{13,14,15)}$ おび Con A などの非 特異的 mitogen によるT細胞の幼若化反応 ${ }^{15)}$ に対する 抑制機能が低下していると報告されている，しかし， PWM 刺激 Ig 産生系での検索は乏しく,さらにこの suppressor 細胞は assay 方法の違いにより多様性が認 められ ${ }^{16)}$ ，その前駆細胞も異なると考えられている17,18， 19)。さらに，ヒトSLE でも自己免疫系マウスにみられ るようなB 細胞レベルの異常も考えられるので, SLEの suppressor 細胞機能を測定する場合には, SLE のB細 胞の Ig 産生機能に対する抑制効果のみならず，正常ヒ トB 細胞の Ig 産生機能に対する抑制効果についても検 討する必要がある。

本稿では, Con A-induced suppressor 細胞と, preculture-induced suppressor 細胞 ${ }^{20,21)}$ の機能を同時に 測定することにより，SLE の単核球による in vitro で
の Ig 産生異常の T細胞レベルでの解析を試みた. その 結果, SLE ではこれら両 suppressor 細胞は正常に誘 導されるにもかかわらず，自己のB細胞による Ig 産生 に対しては十分に抑制効果を発揮しないことが判明し た.

\section{II. 対象と方法}

\section{1. 対 象}

アメリカリウマチ協会の診断基準をみたし，当科で SLE と診断された入院患者, 女性 7 例, 男性 4 例の計 11 名を対象とした．2例の未治療例を除き，全例 $40 \mathrm{mg} /$ 日ないし $10 \mathrm{mg} /$ 日の prednisolone の投与を受けてお り，うち 1 例は azathioprine $50 \mathrm{mg} /$ 日を併用してい た. 痽病期間および疾患活動性はさまざまであるが, 低 補体価 $\left(\mathrm{CH}_{50}<20\right)$ ，抗 ds-DNA 抗体価高值 (ds-DNA binding activity $>10 \%)$ を示し，臨床的に活動期にあ ると考えられた症例は 7 例であった.

対照として正常人 10 例について抑制機能を測定した.

\section{2. 末梢単核球の分離}

末梢静脈より採血し，ガラスビーズによりフィブリン および血小板を除去した，培羡液 RPMI-1640 にて2〜 3 倍に希釈後, Ficoll-Conray 液に静かに重層し, 1,550 r.p.m. $(400 \mathrm{G})$ で 30 分間遠沈後, 境界面に浮遊寸る単 核球層を取り出した. 培養液にて 3 回洗浄し末梢単核球 浮遊液とした。

\section{3. suppressor 細胞の誘導}

Schwartz らの方法 ${ }^{20)}$ に準じ, suppressor 細胞を誘 導した. すなわち, RPMI-1640 に非傎化ウシ胎児血清 (FCS) と penicillin G (PC-G) 100 万単位/l および streptomycin (SM) $100 \mathrm{mg} / \mathrm{l}$ を含む培養液を用いて, 生細胞数を $1 \times 10^{6} / \mathrm{m} l$ に調製して 2 本の培養試験管 （Falcon 社製 \#3033）に5 cc ずつ分注したのち, 一方 にCon A (SIGMA 社製) $50 \mu \mathrm{g}$ を添加した. $5 \% \mathrm{CO}_{2}$ incubator 中で $37^{\circ} \mathrm{C}$ で 48 時間培趇し, Con A-induced suppressor 細胞および preculture-induced suppressor 細胞を誘導した. 培養終了後 $0.1 \mathrm{M} \alpha$-Methyl-D-Mannoside ( $\alpha$-MMS, SIGMA 社製 Grade III) を含む RPMI1640 にて 3 回洗浄後, さらに RPMI-1640 で 1 回洗浄 して, PWM 刺激 Ig 産生采への Con A の混入を避け た.

\section{Ig 産生用単核球培養}

培漼液は，あらかじめ in vitro Ig 産生に対して刺激 
作用の少ないことを確めた FCS $10 \%$ と，PC-G 100 万年位 $/ l$ および SM $100 \mathrm{mg} / l$ を含む RPMI-1640を用 いた. 健康正常人より単核球を新たに分離し，血清中の Ig の混入を避けるため RPMI-1640にて 5 回洗浄した. 生細胞数を $1 \times 10^{6} / \mathrm{ml}$ に調製して上記培養液に再浮遊 し responder 細胞とした.

Con A 刺激細胞および preculture 細胞も同様に生細 胞数を $1 \times 10^{6} / \mathrm{m} l$ に調製しこの培養液に再浮遊した.

細胞浮遊液 $1 \mathrm{~m} l$ を培養試験管 (Falcon 社製. \$3033) に分注し, PWM (GIBCO 製) $10 \mu l / \mathrm{ml}$ を添加後，5\% $\mathrm{CO}_{2}$ incubator 中で $37^{\circ} \mathrm{C}$ で 9 日間培羕した. 培養終了 後, 2,000 r.p.m. で 10 分間遠沈し培養上清を村田式ピ ペットにて採取し $-20^{\circ} \mathrm{C}$ で保存した.

\section{5. 培養上清中の $I g$ 量の測定}

筆者らの報告のように ${ }^{22)}$ ，二抗体法 radioimmunoassay (RIA) にて培童上清中の IgG, IgA および IgM を 測定した.すなわち, 各種骨髄腫およびマクログロブリ ン血症患者の血清から各種 Ig を精製し, Chloramin $\mathrm{T}$ 法にて ${ }^{125}$ 標識 Ig を作製した. 標準曲線用の精製 Ig または各培養上清 $0.1 \mathrm{~m} l$ と 1/1000 1/2500の正常ウサ ギ血清を含む $1 \%$ BSA-PBS にて，1/2000に希釈した 抗各種 $\mathrm{H}$ 鎖ウサギ血清 $0.1 \mathrm{~m} l$ とを室温にて 90 分閒反 応させ, 次に約 $20,000 \mathrm{cpm} / 0.1 \mathrm{ml}$ (Ig 量として $1 \mathrm{ng}$ 以下) となるように希釈した各種標識 $\mathrm{Ig}$ 液 $0.1 \mathrm{~m} l$ を 加え，さらに 90 分間反応させた.ついで $1 \%$ BSA.PBS にて $1 / 100 \sim 1 / 200$ にて希釈した抗ウサギ $r$-glob. ヤギ血 清 $0.1 \mathrm{ml}$ を添加し, 一晚 $4^{\circ} \mathrm{C}$ にて反応させた. 反応 後 3,000 r.p.m. にて 30 分間遠沈し，上清を除去し，沈 渣中の放射能活性を測定し, 標準曲線から上清 $1 \mathrm{~m} l$ 中 に含まれる Ig 量を求めた。

\section{6. suppressor 活性の測定}

suppressor 活性は, responder 細胞と Con A 刺激細 胞あるいは preculture 細胞を co-culture したときの Ig 産生に対する抑制効果をみることにより測定した。 この両細胞浮遊液を合計 $1 \mathrm{~m} l$ となるように, 1 対 1 , 4 対 1 あるいは他の割合で混合し dose response を観察 した. suppressor 活性は, 1 対 1 co-culture 時の Ig 産 生量から Lipsky らの方法 ${ }^{21}$ により次の式を用いて \% inhibition を算出し suppressor 活性とした.

$\%$ inhibition

$$
=\left[1-\frac{\text { Observed } \mathrm{Ig} \text { secretion }(\mathrm{ng} / \mathrm{m} l)}{\text { Predicted Ig secretion }(\mathrm{ng} / \mathrm{m} l)}\right] \times 100
$$

この式で observed Ig secretion は, 1 対 1 co-culture
時の Ig 産生量実測値を表わす. predicted Ig secretion は， responder 細胞のみから産生される Ig 量と Con A 刺激細胞のみあるいは preculture 細胞のみから産生さ れる $\mathrm{Ig}$ 量の総和の平均である.

\section{III. 結 果}

\section{1. suppressor 細胞の PWM 刺激 Ig 産生培養への 影響}

図1に示すように, 正常ヒトの Con A-induced suppressor 細胞および preculture-induced suppressor 細 胞は, 自己のみならず同種の単核球による PWM 刺激 Ig 産生を抑制した.この両 suppressor 細胞による Ig 産生の抑制は, 加えた suppressor 細胞の濃度に依存性 が認められた. Con A-induced suppressor 細胞は preculture-induced suppressor 細胞より強い抑制能を有 し, responder 細胞の 10\%の濃度でも強い抑制効果が 認められた。

さらに, 興味深いことには, 図2に示すように SLE 患者の Con A-induced suppressor 細胞および preculture-induced suppressor 細胞も正常同種単核球による Ig 産生に対し suppressor 活性が認められた. 正常七 トでは Con A 刺激細胞のみあるいは preculture 細胞 のみを $\mathrm{PWM}$ 添加後さらに培窔しても, 自己のB細胞 に対する強い suppressor 活性のため産生される Ig 量 は $10 \mathrm{ng} / \mathrm{m} l$ 以下となった. しかし, SLE ではこれら Con A 添加あるい訬添加で preculture された細胞を PWM 存在下で培羡すると，Ig 産生は抑制されるにも かかわらずな扔検出可能であり，これらの suppressor 細胞の自己B細胞に対する suppressor 活性の低下を示 していた.

\section{2. 正常ヒトの Con A-induced suppressor 細胞}

responder 細胞の PWM 刺激 Ig 産生量には個体差 が認められた.したがって, suppressor 細胞とのcoculture 時の Ig 産生量で suppressor 活性を相互に比 較することはできない，そこで, responder 細胞のみに よる Ig 産生量を $100 \%$ とし, Con A 刺激細胞あるいは preculture 細胞との co-culture での Ig 産生量を\% secretion で表わした. 図 3 は正常ヒト 10 例の Con A 刺激細胞と正常同種単核球との co-culture の結果を示 している. 10 例とも responder 細胞の PWM 刺激 Ig 産生を強く抑制した。 Ig クラス別にみると，IgG およ び IgA 産生に対する抑制はほぼ似たパターンを示すの に対し，IgM 産生に対してはさらに強い抑制が認めら れた.この抑制効果には, 加えた suppressor 細胞の濃 


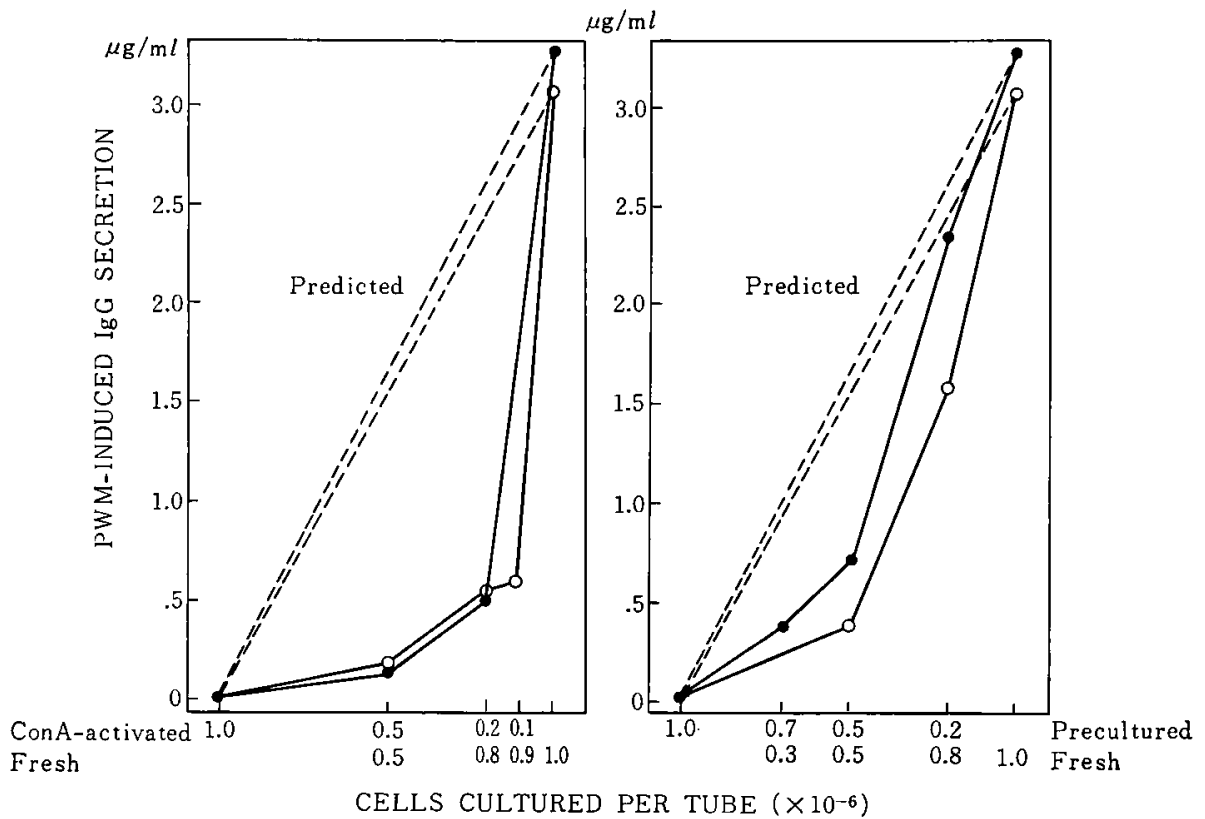

CON-A ACTIVATED CELLS

PRECULTURED CELLS

図 1 Effect of co-culturing ConA-activated or precultured cells from normal individuals with fresh autologous (O) or allogeneic (O) peripheral mononuclear cells on the PWM-induced immunoglobulin secretion.

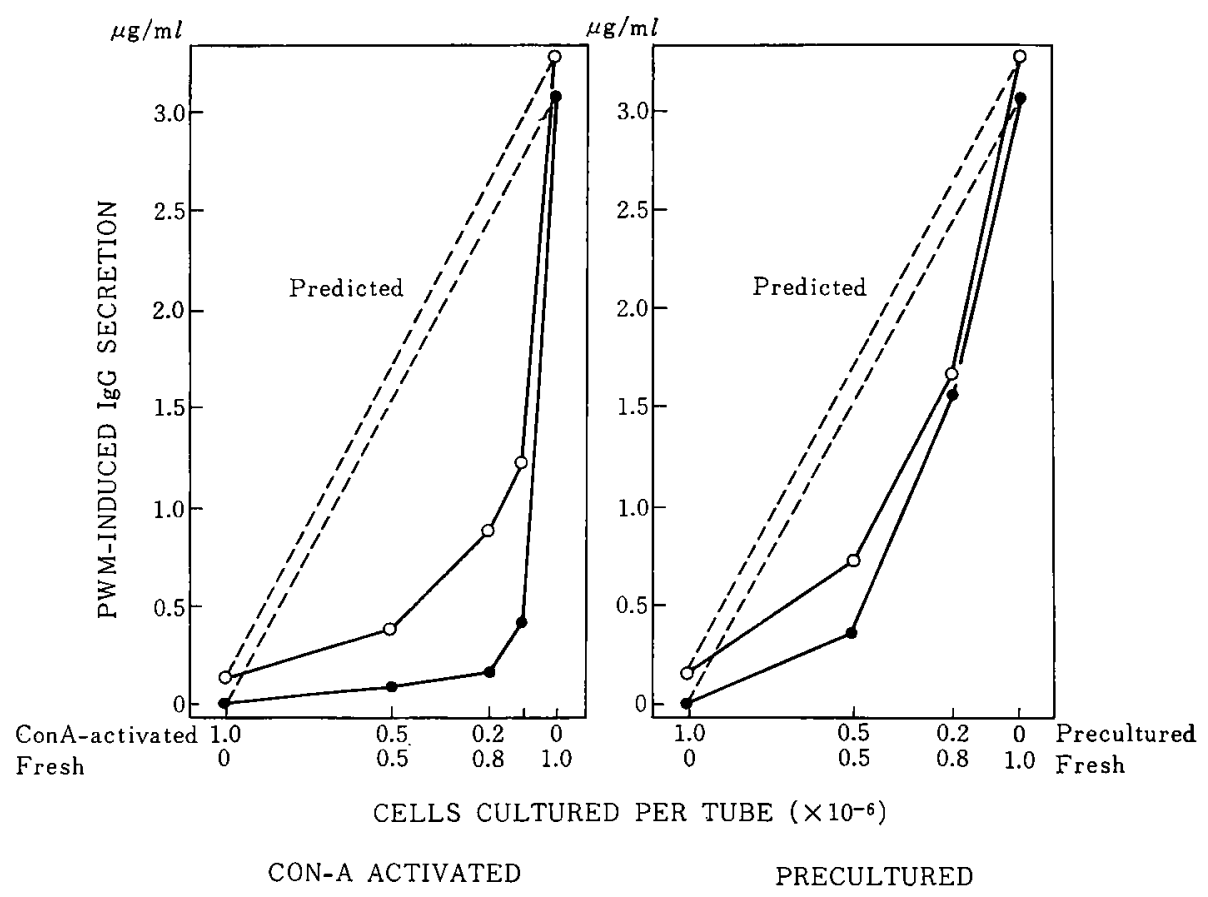

図 2 Typical patterns of suppression by co-culturing ConA-activated cells or precultured cells from a SLE patient $(O)$ or a normal individual (O) with normal fresh allogeneic peripheral mononuclear cells in the PWMinduced immunoglobulin secretion. 


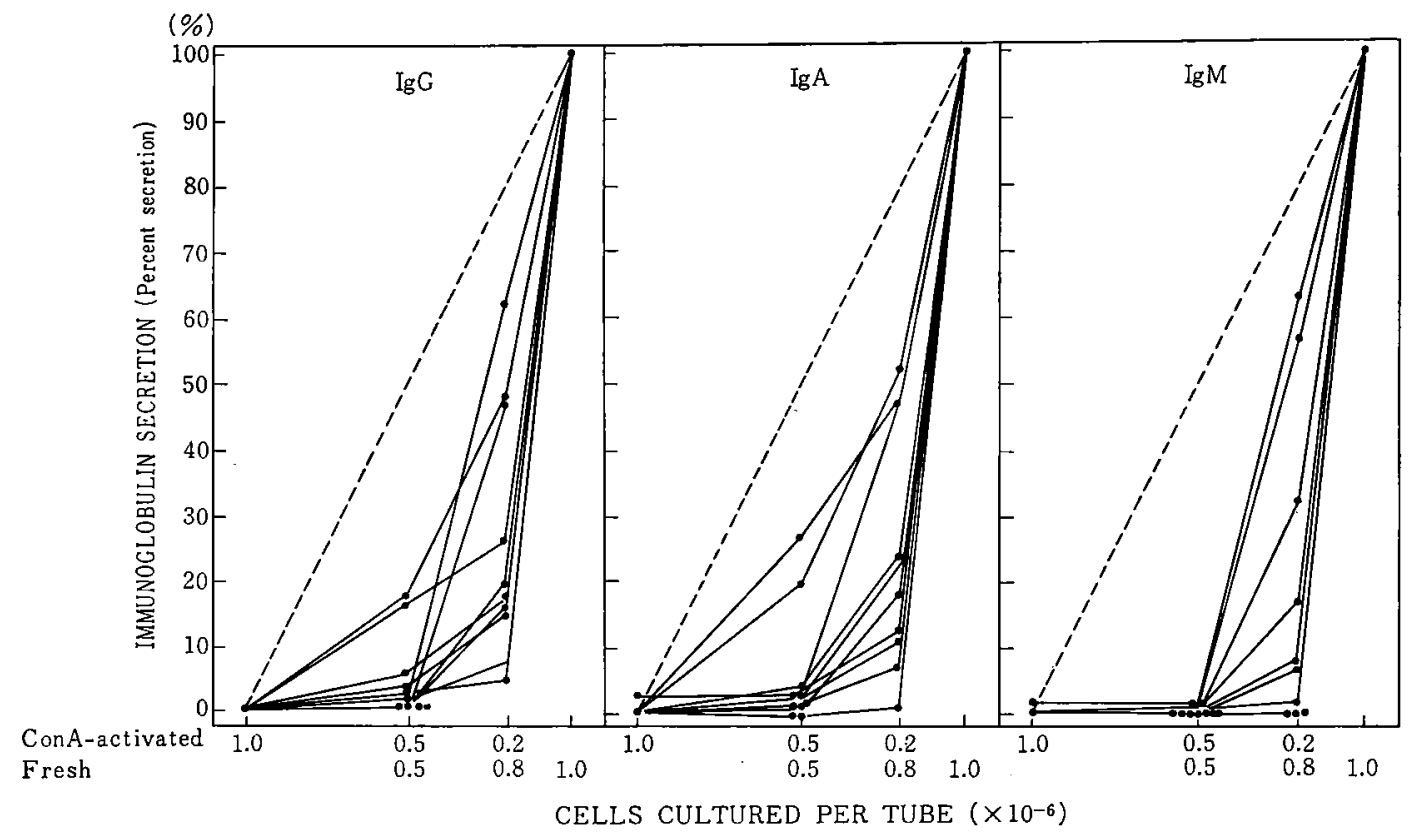

図 3 Effect of co-culturing ConA-activated cells from normal individuals with normal allogeneic peripheral mononuclear cells on the PWM-induced immunoglobulin secretion.

度に依存性が認められたが, responder 細胞の $20 \% の$ 量では suppressor 活性にかなりのひらきが認められた のに対し，1 対 1 co-culture ではほぼ同程度の強い抑制 効果がみられた。

Con A 刺激細胞のみを PWM 存在下でさらに 9 日間 培養しても， IgA および IgM のI例を除いて全例で Ig 産生はまったく抑制されてしまった．このことは，前述 のように前培美で誘導された suppressor 細胞が自己の B細胞に対しても强い抑制効果を有することを示すと考 えられた。

\section{SLE $の$ Con A-induced suppressor 細胞}

図 4 に SLE 患者の Con A 刺激細胞と正常同種単核 球との co-culture の結果を示したが，最も特徽的なこ とは, SLE では Con A 刺激細胞のみを PWM 存在下 にさらに培羑すると，正常ヒトの場合と異なり，依然と して Ig 産生の認められる症例が存在することである. すなわち自己 B 細胞に対する抑制効果の減弱が認められ た. 一方, 正常同種単核球との 1 対 1 co-culture でも \% secretion が正常ヒトの場合より高い症例が認められ る.しかしこれは, Con A 刺激細胞中のB 細胞による Ig 産生が加わるためであり，この場合 Predicted Ig secretion も当然高くなるので, suppressor 活性が低下
しているとは言えない。

\section{Con A-induced suppressor 細胞の活性}

正常ヒト 10 例およびSLE 患者11例の Con A-induced suppressor 細胞の，同種単核球による PWM 刺激 Ig 産生に対する suppressor 活性を図 5 に示した. 正常七 トでは, IgG 産生に対して $89.1 \pm 13.1 \%$, IgA 産生に 対して $90.3 \pm 11.6 \%$, IgM 産生に対して $98.1 \pm 2.2 \%$ と非常に強い suppressor 活性が認められた。

一方 SLE でも，IgG，IgA および IgM 産生に対し てそれぞれ $82.6 \pm 20.6 \% ， 93.2 \pm 7.0 \% ， 95.5 \pm 12.2 \%$ と正常ヒトとほぼ同様に強い suppressor 活性を示した. すなわち，SLE の末梢単核球を Con A で刺激すること により，正常ヒト単核球による PWM 刺激 Ig 産生を 抑制する suppressor 細胞を誘導することができた。

\section{5. 正常ヒトの preculture 細胞}

正常ヒトの未梢単核球を in vitro で 48 時間 preculture すると, 図6のように PWM に対する反応性は失 われ，IgG および IgM の1例を除いて全例で Ig 産生 はみられなかった。この preculture 細胞の同種単核球 に対する抑制効果を co-culture で観察すると，4対 1 co-culture では一部で逆に増強効果が認められたが，1 


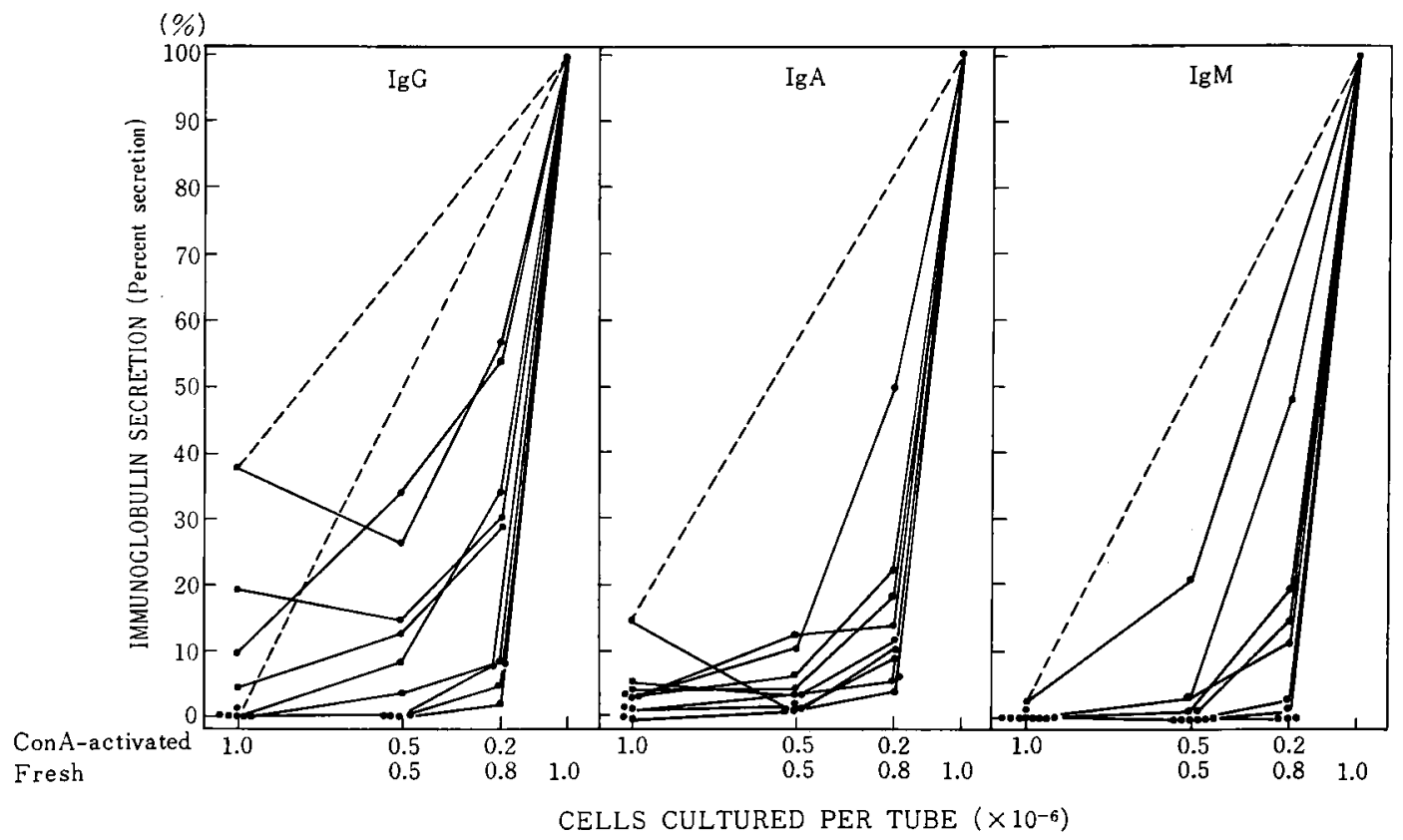

図 4 Effect of co-culturing ConA-activated cells from SLE patients with normal allogeneic mononuclear cells on the PWM-induced immunoglobulin secretion.

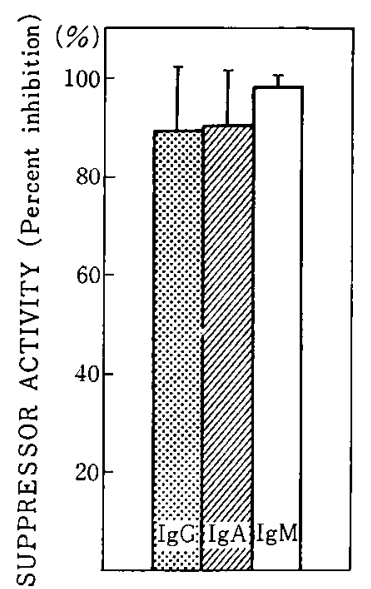

NORMAL INDIVIDUALS

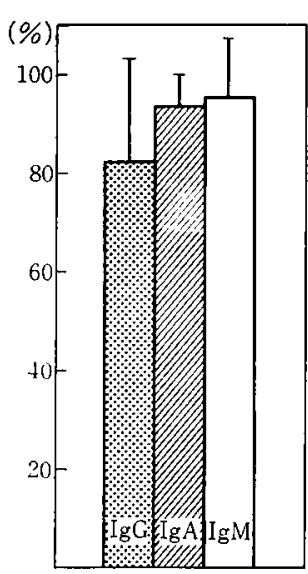

SLE PATIENTS

図 5 ConA-induced suppressor activities of peripheral lymphocytes from normal individuals and SLE patients in the PWMinduced immunoglobulin secretion by normal allogeneic peripheral mononuclear cells.

対 1 co-culture ではほほ全例で同種単核球による Ig 産 生を抑制した。

\section{SLE の preculture 細胞}

SLE 患者の末梢単核球を in vitro で 48 時間 precul-

ture しても，図 7 のうに，なお検出可能な Ig が産生 され, Con A 刺激細胞の場合と同様, 自己 B 細胞に対す る抑制効果の減弱が示唆された.しかし，正常同種単核 球と co-culture すると 1 例を除いて抑制能を示した. また obserbed Ig secretion の高い例が認められるが， これも Con A 刺激細胞との co-culture の場合と同じ 理由によると考えられる。

\section{7. preculture induced suppressor 細胞の活性}

正常ヒト $(n=10)$ では, 1 対 1 の co-culture で IgG 産生に対して $48.0 \pm 27.8 \%, \operatorname{IgA}$ 産生に対して 56.8土 $20.1 \%$, IgM 産生に対して $60.4 \pm 35.2 \%$ と幅広、

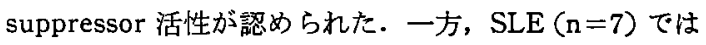
IgG, IgA および IgM 産生に対してそれぞれ 39.8土 $40.1 \% ， 39.5 \pm 29.4 \%$ および $73.7 \pm 26.6 \%$ であった (図 8). IgG および IgA 産生に対する suppressor 活 性は, 正常ヒトよりやや低いが統計学的には有意差は認 められない.すなわち, SLE の単核球を in vitro で 48 時間培養することにより, 正常ヒト単核球による PWM 刺激 Ig 産生を抑制する suppressor 細胞をほぼ全例で 誘導することができた。

\section{8. 自己B細胞に対する抑制効果}

前述のように, Con A 刺激細胞および preculture 細 


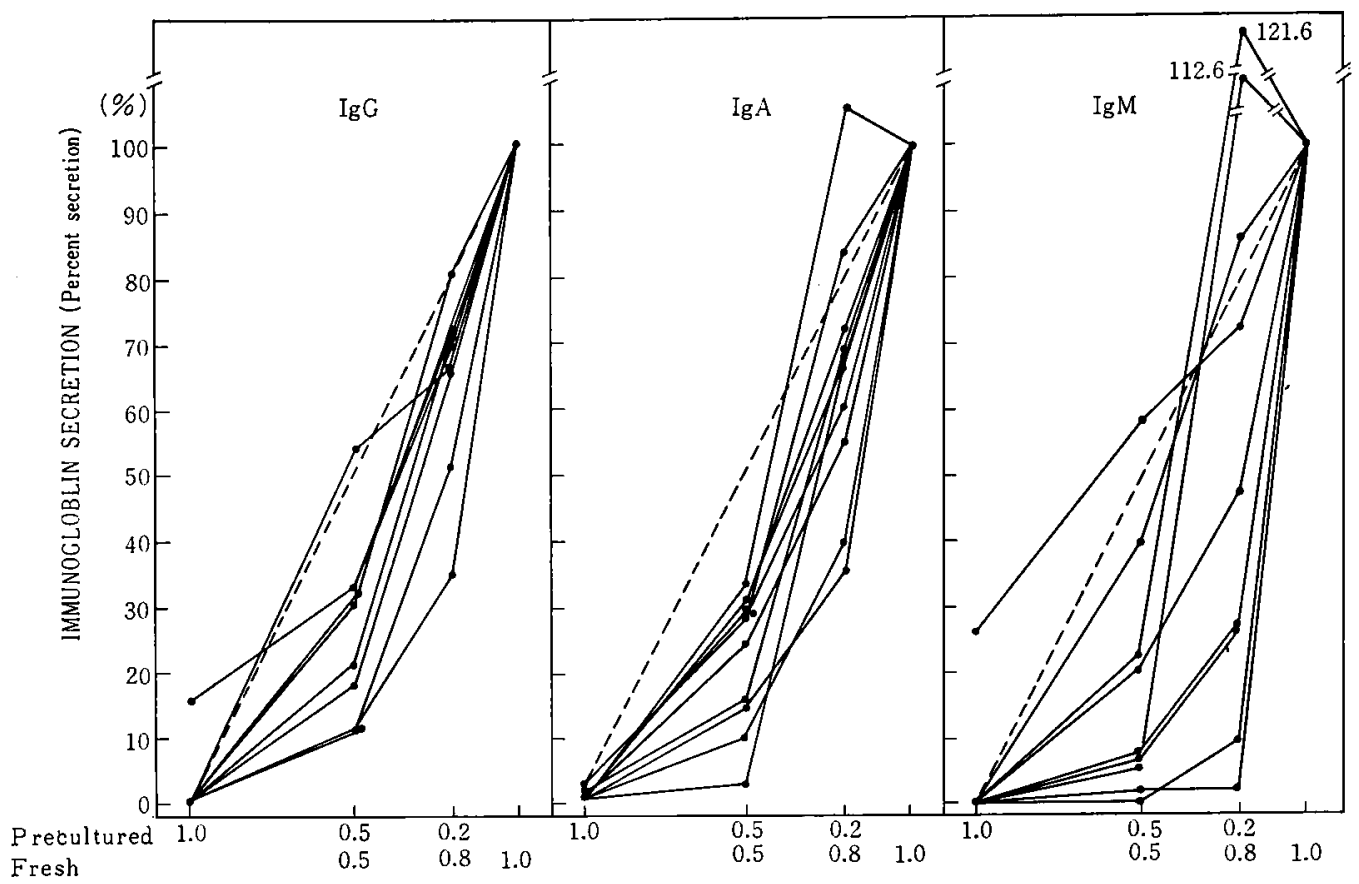

CeLL CELLS CULTURED PER TUBE $\left(\times 10^{-6}\right)$

図 6 Effect of co-culturing precultured normal peripheral mononuclear cells with normal allogeneic peripheral mononuclear cells on the PWM-induced immunoglobulin secretion.

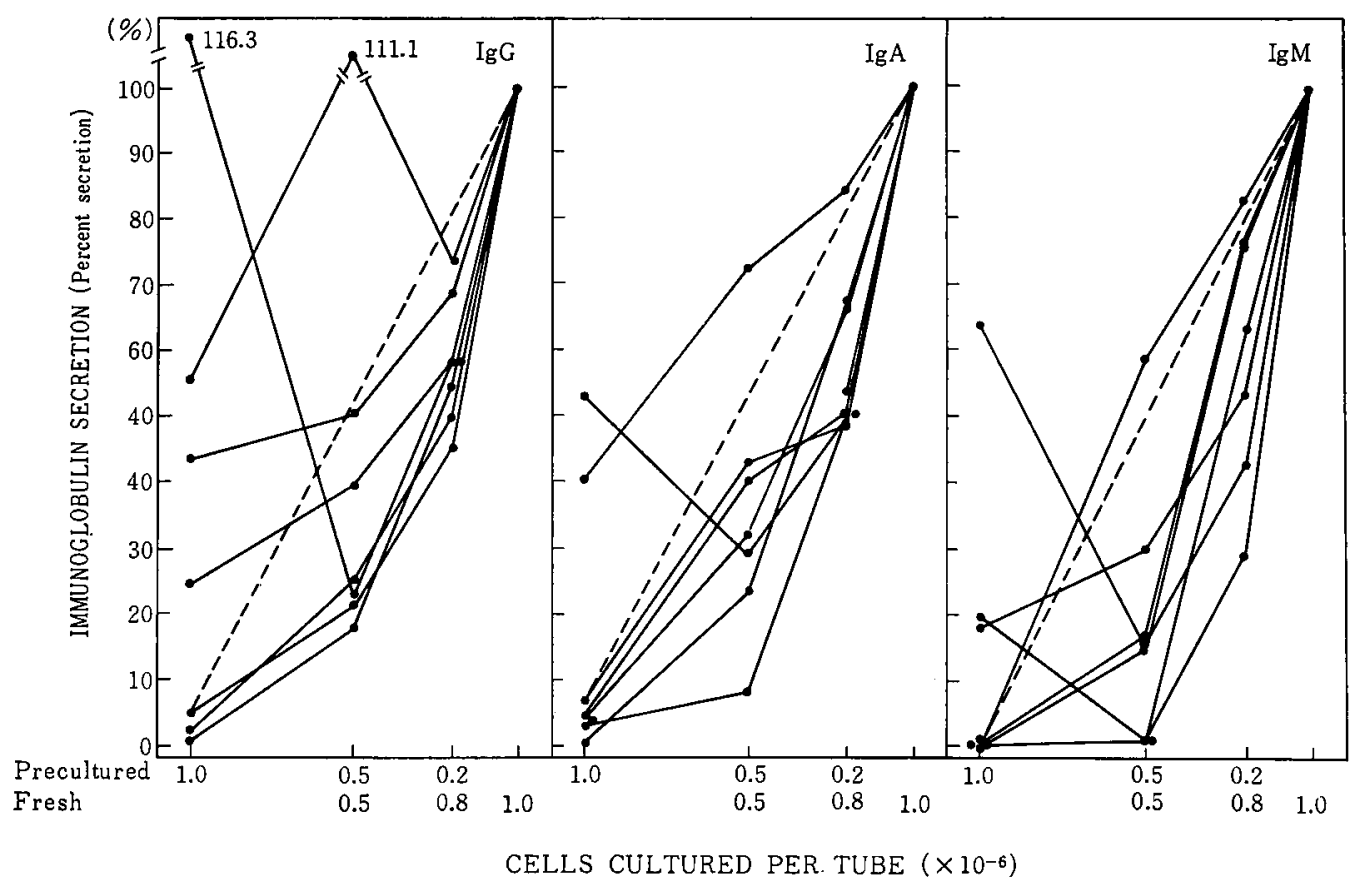

図 7 Effect of co-culturing precultured SLE peripheral mononuclear cells with normal allogeneic peripheral mononuclear cells on the PWM-induced immunoglobulin secretion. 

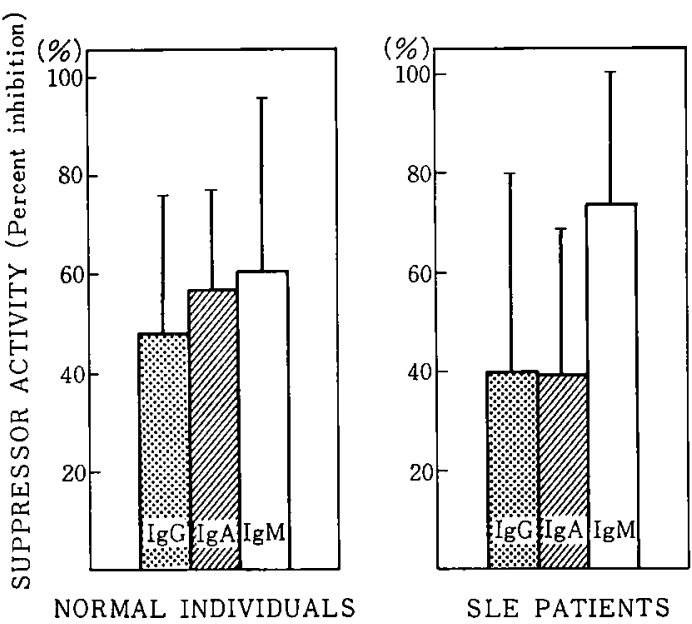

図 8 Suppressor activities of precultured lymhocytes form normal individuals and SLE patients in the PWM-induced immunoglobulin secretion by normal allogeneic peripheral mononuclear cells.

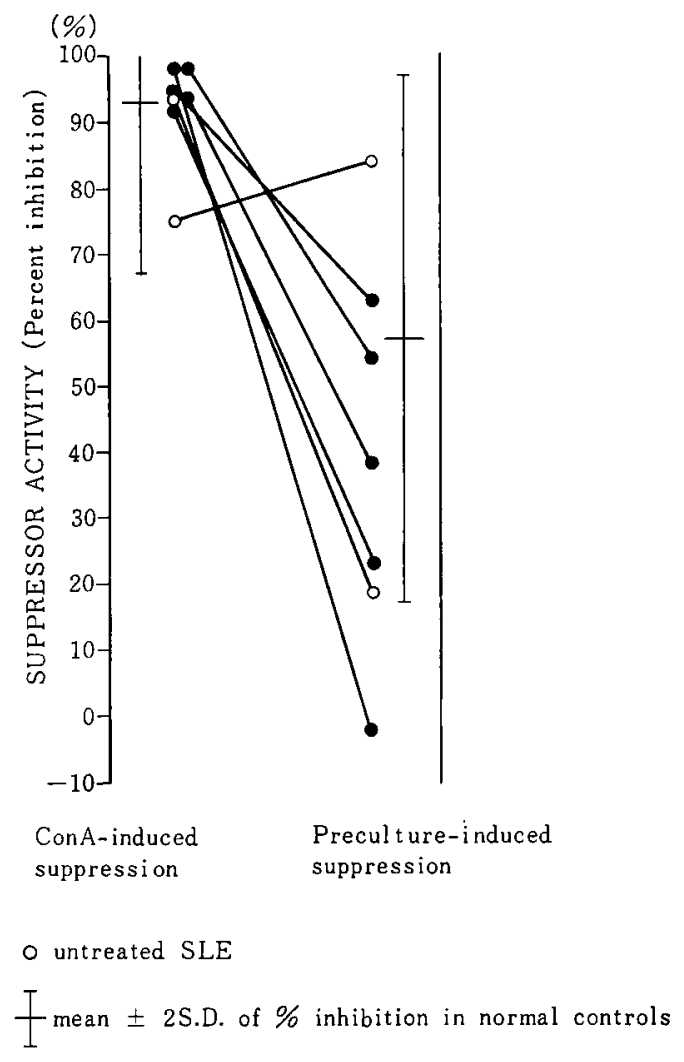

図 10 Reration of two different suppressor systems in pa. tients with SLE.

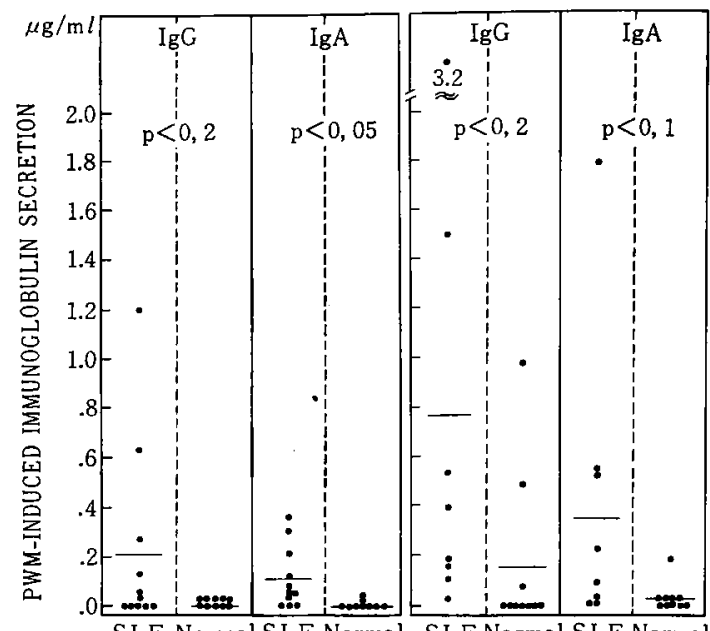

SLE Normal SLE Normal SLE Normal SLE Normal CON-A ACTIVATED CELLS PRECULTURED CELLS

国 9 Impaired suppressor activities of ConAactivated and precultured peripheral lymphocytes from SLE patients in the PWM-induced immunoglobulin secretion by autologous peripheral mononuclear cells. ConA-activated or precultured peripheral mononuclear cells were further incubated for 9 days in the presence of PWM.

胞を洗浄後, PWM を添加してさらに 9 日間培養しても 正常ヒトでは Ig はほとんど産生されない。すなわち， 両 suppressor 細胞とも自己B 細胞には強い抑制能を有 寸る(図 3，6).

一方, SLE では Con A 刺激細胞および preculture 細胞ともに依然として Ig が産生される例が認められた （図 4，7）。すなわち，図9に示すように偏差が大きいた め統計学的には Con A 刺激細胞によるIgA 産生のみ 有意であったが, 正常ヒトと比較すると SLE では自己 B 細胞に対する抑制効果は低下していると考えられる.

\section{9. 両 suppressor 活性の比較と疾患活動性との関連}

Con A-induced suppressor 細胞および precultureinduced suppressor 細胞の IgA 産生に対する suppressor 活性を図 10 に示した. preculture-induced suppressor 細胞の 1 例を除き, SLE の同種単核球の Ig 産 生に対する suppressor 活性は, 正常七トのそれの mean 士2S.D. に含まれる.正常ヒトでは, 全例 Con A-induced suppressor 活性の方が preculture-induced suppressor 活性よりも強かった. SLEでも1例を除きCon Ainduced suppressor 細胞の方が強い suppressor 活性 
を示した.

SLE に括いては, 両 suppressor 細胞とも疾患活動 性, prednisolone 投与量および他の検查成績との関連 は認められなかった。特に，抗 RNP 抗体㧍よび抗T細 胞抗体の有無とも関倸はみられなかった.

\section{IV. 考察}

Con A-induced suppressor 細胞は，自己のみならず 同種単核球による PWM 刺激 Ig 産生を抑制する ${ }^{19,20}$, 23).この抑制作用は細胞障害によるものではないと考え

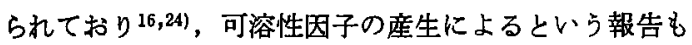
ある ${ }^{24)}$.また, この抑制効果は PWM 刺激 Ig 座生系へ の Con A の混入による, responder 細胞中の suppressor 前駆細胞の活性化によるものではない，ちなみに， 本稿にデータは示してはいないが, Con A の混入の有無 を検索するために，Con A で 1 時間だけ incubate し たのちに $\alpha$ MMS で同様に洗浄し，PWMで刺激して ๖. Con A 非添加の場合と Ig 産生量に差は認められな かった.

ヒト単核球を 24 時間以上 preculture すると，PWM 刺激 Ig 産生を抑制する suppressor $\mathrm{T}$ 細胞が出現す $ろ^{20,21)}$. 48 時間の preculture ではこの suppressor T 細胞は自己のB細胞に対しては強い抑制効果を発揮する が，同種 B 細胞に対しては抑制的ないし増殖的に働くと いう報告もあり ${ }^{20)}$, 実際今回の実験でも少数例では helper 作用が認められた。より十分な suppressor 細 胞の誘導には 3 日以上の preculture が必要であるとさ れているが21)，今回の実験では同時に採取した細胞の Con A-induced suppressor 活性と preculture-induced suppressor 活性を比較するため 48 時閒の preculture で誘導してみた.この preculture-induced suppressor 細胞も MHC (major histocompatibility complex) バ リアーを越えて働くが20,21)，細胞障害によるものではな いと考えられている21).

SLE ではこの両 suppressor 細胞とも正常ヒトの場 合と同様, 正常同種単核球による PWM 刺激 Ig 産生 を抑制した。すなわち, SLE の単核球を Con A 添加あ るいは非添加のもとに in vitroで培養することにより， 正常七トと同様に PWM 刺激 Ig 産生を抑制する suppressor 細胞を誘導することができた. Fauci ら ${ }^{6)}$ は， PWM-induced plaque-forming cell (PFC) assay で

文

1) Waldmann, T.A., Durm, M., Broder, S. et al : Role of suppressor $T$ cells in pathogenesis of
SLE の Con A-induced suppressor 細胞の 正常同種単 核球に対する suppressor 活性を検索し, 統計学的に有 意ではないが, SLE では正常同種単核球による Ig 産生 に対する suppressor 活性が低下していると報告してい る.しかし, 彼らは suppressor 活性を 1 対 1 co-culture 時の Ig 産生細胞数で比較しており,これでは前述のよ うに SLE の異常なB細胞によるIg 産生も加わるため, 正確には\% inhibition で suppressor 活性を評価すへ きであろう.

一方, SLE ではこれら両 suppressor 細胞は自己のB 細胞による Ig 産生を十分に抑制することはできなかっ た. Ruiz-Arguelles ら ${ }^{25}$ は, SLE 患者から新たに採取 した自己の単核球のみを responder 細胞として用い, PWM 刺激 Ig 産生に対するこれら両 suppressor 活性 を今回とほぼ同様に测定し，検索した SLE 患者の $68 \%$ に両 suppressor 活性の低下を認めたため, SLE では suppressor 細胞の誘導が障害されていると結論してい る. しかし, 彼らは SLE B 細胞が suppressor 細胞に 不応性であることを考虑しなかったため, 正常ヒトB細 胞に対する suppressor 活性をみておらずこのような結 論に達したのであろう.

SLE では，末梢T細胞の減少あるいは IgG Fc リ七 プター陽性細胞の減少になど, 確かに T細胞系の異常が 認められる. 今回の検索でも一部の症例では, 正常同種 単核球による PWM 刺激 Ig 産生に対する precultureinduced suppressor 活性の低下が観察されたが，これ は末梢T細胞の減少が関与していると考えられる.ま た, MLC ${ }^{13,14,15)}$ および Con A によるT細胞の幼若化 反応 $\left.{ }^{15}\right)$ に対する Con A-induced suppressor 細胞の機能 低下が報告されているが, Con A によるT細胞の幼若 化反応の系で suppressor 活性を測定する方法は最近欠 点が指摘されておう 26,27)，MLCにおいても真の意味の 機能を検索しているとは考えられず，あまり適当な方法 ではない。

いずれにしても，SLE ではこのようにT細胞系にも 異常が認められることは確かで, 病態をより複雑にして いると考えられる. しかし, in vitro での抗体産生異常 はむしろB細胞自体に原因があると考えられ，in vivo ですでにB細胞が preactivate されていることが強く示 唆され，これまでの筆者らの成績)を強く裹付けている.

献

common variable hypogammaglobulinemia. Lancet ii : 609 613, 1974. 
2) Siegal, F.P. \& Siegal, M. : Enhancement by irradiated $T$ cells of human plasma cell production. Dissection of helper and suppressor functions in vitro. J. Immunol., $118: 642 \sim 647$, 1977.

3) Saxon, A., Stevens, R.H. \& Ashman, R.F. : Regulation of immunoglobulin production in human peripheral blood leukocytes. Cellular interactions. J. Immunol., $118: 1872 \sim 1879$, 1977.

4) Asano, T., Yano, K. \& Ofuji, T. : Immunological dysregulation in SLE. In ; Abstracts of 4th International Congress of Immunology. Ed. by Preud'Homme, J.L. \& Hawken, V.A.L. Imp. Amelot. Paris. Abst. No. 18.8.05., 1980.

5) Blaese, R.M., Grayson, J, \& Steinberg, A.D. : Increased immunoglobulin secreting cells in the blood of patints with active systemic lupus erythematosus. Am. J. Med., $69: 345 \sim 350$, 1980.

6) Fauci, A.S., Steinberg, A.D., Haynes, B.F. et al. : Immunoregulatory aberrations in systemic lupus erthematosus. J. Immunol., $121: 1473 \sim$ 1479, 1978.

7) Theofilopoulos, A.N., Shawler, D.L., Eisenberg, R.A. et al. : Splenic immunoglobulin-secreting cells and their regulation in autoimmune mice. J. Exp. Med., 151 : 446 466, 1980.

8) Krakauer, R.S., Waldmann, T.A. \& Strober, W. : Loss of suppressor $T$ cells in adult NZB/ NZW mice. J. Exp. Med., $144: 662 \sim 673,1976$.

9) Gershon, R.K. : Suppressor T cell dysfunction as a possible cause for autoimmunity. In ; Autoimmunity. Ed. by Talal, N., Academic Press. New York. : 171 180, 1977.

10) Theofilopoulos, A.N., McConahey, P. J., Izui, S. et al. : A comparative immunologic analysis of several murine strains with autoimmune manifestations. Clin. Immunol. Immunopathol., $15: 258 \sim 278,1980$.

11) Cohen, P.L. \& Ziff, M. : Abnormal polyclonal $B$ cell activation in $\mathrm{NZB} / \mathrm{NZW} \mathrm{F}_{1}$ mice. $\mathrm{J}$. Immunol., $119:$ 1534 1537, 1977.

12) Primi, D., Hammarstroem, L. \& Smith, C.I.E. : Genetic control of lymphocyte suppression. I.
Lack of suppression in aged NZB mice is due to a B cell defect. J. Immunol., $121: 2241 \sim$ 2243, 1978.

13) Horowitz, S., Borcherding, W., Moorthy, A.V. et al. : Induction of suppressor $T$ cells in systemic lupus erythematosus by thymosin and cultured thymic epithelium. Science, 197 : 999 1001, 1977.

14) Kaufman, D.B. \& Bostwick, E. : Defective suppressor $\mathrm{T}$-cell activity in systemic lupus erythematosus. Clin. Immunol. Immunopathol., $13: 9 \sim 18,1979$.

15) Sakane, T., Steinberg, A.D. \& Green, I. : Studies of immune functions of patients with systemic lupus erythematosus. I. Dysfunction of suppressor $T$-cell activity related to impaired generation of, rather than response to, suppressor cells. Arthritis Rheum., 21 : $657 \sim 664,1978$.

16) Lobo, P.I. \& Speucer, C.E. : Inhibition of humoral and cell-mediated immune responses in man by distinct suppressor cell systems. J. Clin. Invest., $63: 1157 \sim 1163,1979$.

17) Theofilopoulos, A.N., McConahey, P.J., Izui, S. et al. : A comparative immunologic analysis of several murine strains with autoimmune manifestations. Clin. Immunol. Immunopathol., $15: 258 \sim 278,1980$.

18) Haynes, B.F. \& Fauci, A.S. : Activation of human B lymphocytes. X. Heterogeneity of concanavalin A-generated suppressor cells of the pokeweed mitogen-induced plaque-forming cell response of human peripheral blood lymphocytes. J. Immunol., $121: 559 \sim 565,1978$.

19) Sakane, T. \& Green, I. : Human suppressor T cells induced by concanavalin A. Suppressor $T$ cells belong to distinctive $T$ cell subclasses. J. Immunol., 119 : 1169 1178, 1977.

20) Schwartz, S. A., Shou, L., Good, R.A. et al. : Suppression of immunoglobulin synthesis and secretion by peripheral blood lymphocytes from normal donors. Proc. Natl. Acad. Sci., 74 : 2099 2103, 1977.

21) Lipsky, P.E., Ginsberg, W.W., Finkelman, F.D. et al. : Control of human B lymphocyte 
responsiveness. Enhanced suppressor $\mathrm{T}$ cell activity after in vitro incubation. J. Immunol., $120: 902 \sim 910,1978$.

22）矢野啓介, 浅野太郎, 大藤 員: Staphylococcal phage lysate (SPL)一多クローン性B細胞活性化 物質. 医学のあゆみ，115:264 266，1980.

23) Kuritani, T., Hirano, T., Kishimoto, T, et al. : In vitro immune response of human peripheral lymphocytes. II. Properties and functions of concanavalin A-induced suppressor $T$ cells. Microbiol. Immunol., $23: 185 \sim$ 196, 1979.

24) Krakauer, R.S., Cathcart, M.K. \& Ilfeld, D.N. : Suppression of polyclonal immunoglobulin biosynthesis by a soluble factor. $T$ cell dependent and $\mathbf{T}$ cell independent mitogens. Immu- nology. $40: 53 \sim 60,1980$.

25) Ruiz-Arguelles, A., Alarcon-Segovia, D., Ilorente, L. et al. : Heterogeneity of the spon. taneously expanded and mitogen-induced generation of suppressor cell function of $T$ cells on $B$ cells in systemic lupus erythematosus. Arthritis Rheum., $23: 1004 \sim 1009,1980$.

26) Feighery, C., Whelan, C.A., Weir, D.G. et al. : In vitro studies of suppressor cell function in human peripheral blood mononuclear cells. Clin. exp. Immunol., $32: 459 \sim 465,1978$.

27) Fernandez, L.A. \& Macsween, J.M. : Generation of suppressor cells by concanavalin A. A new perspective. J. Immunol., $125: 267 \sim 269$, 1980. 